\title{
A földtudományok szerepe az élöhelytérképek készítésében és értelmezésében délkelet-magyarországi példák alapján
}

\author{
Deák József Áron, Rakonczai János és Ladányi Zsuzsanna \\ Szegedi Tudományegyetem, Természeti Földrajzi és Geoinformatikai Tanszék, \\ 6722 Szeged, Egyetem u. 2. \\ e-mail:aron@geo.u-szeged.hu
}

\begin{abstract}
Összefoglaló: A természetföldrajzi adottságok és változásaik befolyásolják a természetvédelem objektumainak (fajok, közösségek, tájak) megjelenését, térbeli mintázatát, állapotát. Délkelet-Magyarországon a makroklimatikus különbségek helyett a felszíni üledékek, a vízellátottság és a geomorfológia szerepe hangsúlyosabb a talajok és a biológiai entitások térbeli mintázatában. A földrajzi háttértényezők alapján a vizsgált területen homoki, lösz- és ártéri tájtípusok találhatók. A homoki tájak a garmada-buckamezők vagy a lepelhomok-hátak dominanciája alapján különülnek el, szélvájta mélyedéseik élöhelyi mintázatát, azok felszín közeli üledékei, a talajvízáramlások, a csapadékbevétel, a párolgás és a sófelhalmozódás befolyásolja. A lösszel fedett hordalékkúp-síkságok élőhelyi mintázatát a jégkorszaki felszíni formakincs határozza meg, de jelentős a felszíni leöblítés és a legeltetés irányította padkaerózió szerepe is. Az ártereken az elöntés vagy annak hiánya, kiszámíthatatlansága befolyásolja leginkább a táji mintázatot a geomorfológia és a tájhasználat mellett, ami jelentős élőhelyi diverzitást hoz létre. A vegetáció térképezésére használt különböző léptékü élőhelytérképek egyben az abiotikus adottságok térbeli mintázatára is utalnak. A recens hazai földrajzi adatbázisok azonban csak tájléptékben segítenek a vegetációmintázat értelmezésében.
\end{abstract}

Kulcsszavak: földtudományok, tájökológia, élőhelyek, tájmintázat, abiotikus adottságok, Alföld, alföldi vegetáció, élőhelytérképezés

\section{Bevezetés}

A természetföldrajzi (geológiai, éghajlati, geomorfológiai, hidrológia, talajtani) adottságok, azok térbeli mintázata, kölcsönhatásai és változásai alapvetően befolyásolják a fajok, közösségek megjelenését, térbeli mintázatát, mennyiségi és minőségi jellemzőit és azok változásait is. A természetföldrajzi háttértényezök és azok változásai legközvetlenebbül a növényzeten keresztül érzékelhetők. A természetföldrajzi háttértényezők és kölcsönhatásaik az Általános Nemzeti Élőhelyosztályzó Rendszerben (ÁNÉR) is visszaköszönnek (Bölöni et al. 2011), ahol az egyes élöhelyek, mint felszínborítási egységek tükrözik a terület növény- 
zetét, a tájalkotó tényezők közti specifikus kapcsolatokat is. A természetföldrajzi adottságok és változásaik az állatvilágot is befolyásolják (különösen a felszíni vizekhez vagy talajhoz közvetlenebbül kötődőket), ám az egyes természetföldrajzi tényezők súlya taxonfüggő. A természetföldrajzi tényezők és azok változásai különböző időléptékben hatnak az élővilágra: közvetlen gyors, de akár késleltetett hatás is lehet egy-egy változás (pl. elöntés, aszály, hirtelen lehulló csapadék) után. A legmarkánsabb, leggyakoribb változások főleg a geomorfológiai, a hidrológiai és a talajadottságokat érintik. Azonban a tájhasználat, az emberi beavatkozások a természetföldrajzi háttértényezőket is módosítják. A természetföldrajzi háttértényezők, s változásaik befolyásolják a természetvédelmet, annak aktuális kihívásait is, de egyben a földtudományok segítséget is nyújtanak a döntéshozatalban, a természeti értékek és azok változásainak dokumentálásában, a folyamatok értelmezésében. Jelen munka igyekszik feltárni a Délkelet-Magyarország vegetációtájainak (Molnár et al. 2008) 3 fö tájtípusában (homoki, lösz és ártéri tájak) a természetföldrajzi adottságok kölcsönhatásaként megjelenő vegetációmintázatot, tájmintázatot, a tájak müködését befolyásoló abiotikus adottságokat kisebb, lokális területeken keresztül (1. ábra), felhasználva a MÉTA-élőhelytérképezés során összegyült táji tapasztalatokat, összehasonlítva a vegetáció mintázatát a földtu-

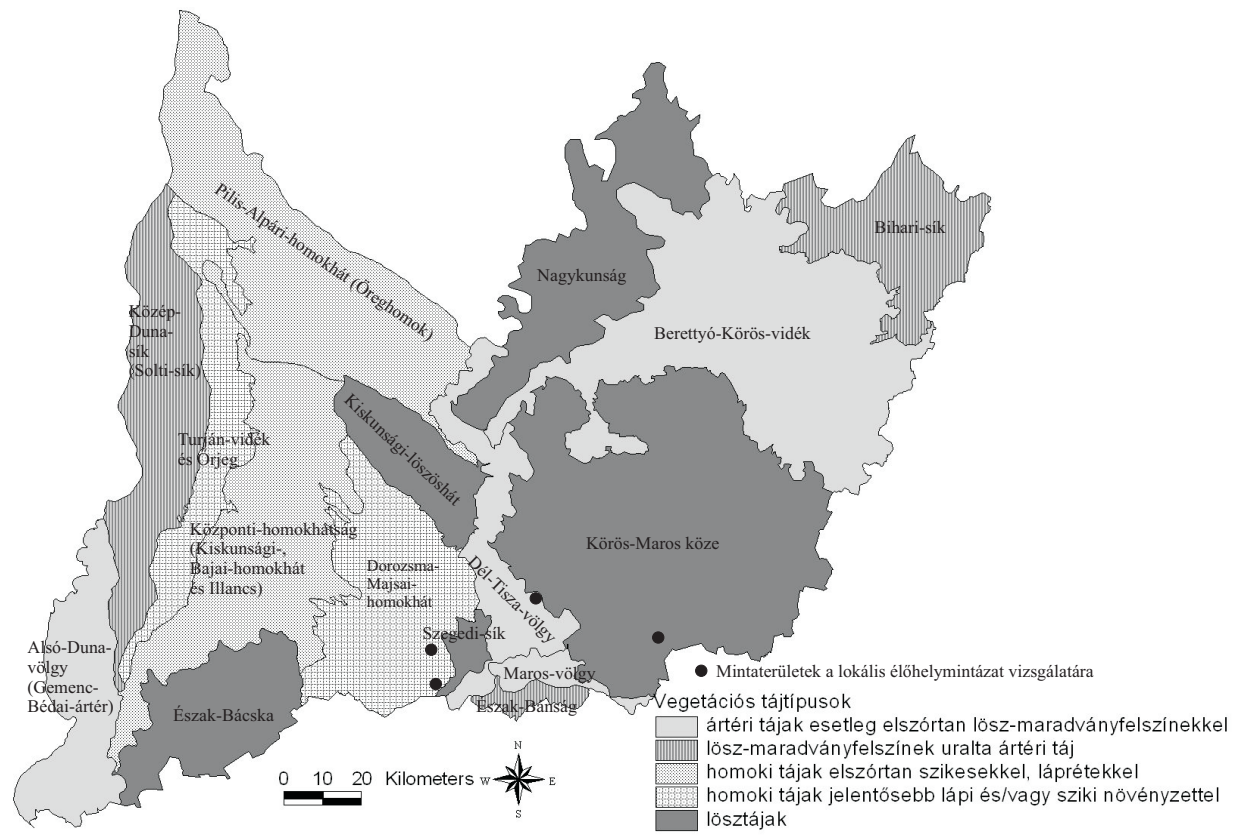

1. ábra. A lokális és a tájszintủ vegetációvizsgálat mintaterületei DK-Magyarország módosított, vegetációs tájtípusokra színezett vegetációtáj-térképén (Molnár Cs. et al. 2008 alapján módosítva). 
dományok szaktérképeivel, a történeti térképekkel és a terepi földrajzi adatgyüjtéssel. A lokális élőhelymintázat és annak földrajzi hátterének feltárása kulcsfontosságú az egyes tájtípusok müködésének, fenntartható használatának megértése szempontjából. Ezen kapcsolatrendszerek tájtípus-, élőhelykomplex-specifikusak.

\section{Módszerek}

A földrajzi háttértényezők és a vegetációmintázat összevetésére elsősorban tájléptékü térképek állnak rendelkezésre, de az összevetésnek a térbeli felbontáson kívül sokszor más akadályai is vannak. A vizsgált terület felszíni üledékeinek értékelésére az 1:200.000-es Alföld Földtani Atlasza sorozat (Rónai et al. 1974, 1978, 1979, 1980, 1983, Kuti et al. 1991) és az 1:100.000-es digitális felszíni üledéktani térképek (MÁFI 2005) lettek felhasználva. Kielégítő részletességü geomorfológiai térkép nem áll rendelkezésre sem lokális, sem országos szinten, bár a térképezés módszertana megvan (Borsy 1992, Lóczy \& Veress 2005, Lóczy 2008, Mezősi \& Rakonczai 1997). Így a felszínformák terepbejárás során lettek azonosítva. A vizsgált terület tájszintü éghajlati jellemzői Magyarország éghajlati atlasza (Merisch et al. 2001) alapján értékelhetők. A talajvíz mélysége és változásai a - már archívnak tekinthető - 1:200.000-es talajvízszint térképek (Kuti et al. 1991, Rónai \& Boczán 1966, Rónai et al. 1974, 1978, 1979, 1980, 1983) és Szalai (2011) országos léptékü, a XXI. századra bekövetkezett jellemző talajvízszint-változásokat bemutató térképei alapján lettek értékelve. A talajok tájszintü térbeli mintázatának értékeléséhez a Kreybig-féle talajtérképek (MKFIMÁFI 1934-1951), valamint a talajok fizikai féleségére (Mattyasovszky et al. 1967, AGROTOPO 2002) és genetikai talajtípusaira (Takács 1989, AGROTOPO 2002) vonatkozó táji, országos léptékü, frissebb térképek lettek felhasználva. A lokális élőhelymintázatok talajtani hátterének értékeléséhez azonban a korábbi lokális talajtérképezések (pl. egykori Tsz-ek üzemtervi térképei (NTSZ 1980)) feledésbe merülő adatai, a terepi talajmintavételezések és minták labor vizsgálata során (lásd pH, összsó-tartalom, szerves anyagtartalom meghatározás) kapott eredmények voltak legalkalmasabbak. Az alkalmazott földtudományokból kinőtt távérzékelés termékei (müholdfelvételek, légifelvételek) nélkülözhetetlenek a természetvédelmi értékek feltárásában, a biodiverzitás-monitoringban, azok a vegetációtérképezés alapvető eszközei. Az országos vagy táji léptékű vegetációtérképezések során a müholdfotók (lásd MÉTA-program (Molnár et al. 2007) során SPOT-4 (CNES 1998) felvételek), míg a lokális élőhelytérképezéseknél (pl. Natura 2000-es területek) a sokkal jobb felbontású légifelvételek (FÖMI 2005) alkalmazása elterjedtebb (lásd a tájtípusok mintaterüleinél), amelyeken már mé- 
teres pontossággal meghatározhatók az élöhelyfoltok. A vegetáció mintázatának bemutatására használt élőhelytérképek jelkulcsa az ÁNÉR (Bölöni et al. 2011).

\section{Eredmények}

Délkelet-Magyarországon a makroklimatikus különbségek helyett a felszíni üledékek, a vízellátottság és a geomorfológiai adottságok mintázatai jobban magyarázzák a talajok és a biológiai entitások térbeli mintázatát. A földrajzi háttértényezők és a vegetáció kapcsolata alapján homoki, lösz és ártéri tájtípusok különíthetők el, de ezeken belül további jellegzetes élőhelyi összetételü élőhelykomplexek is azonosíthatók, amelyek aránya kistájspecifikus lehet. Az alábbiakban az egyes vegetációs tájtípusokra jellemző élőhelymintázat és a földrajzi háttértényezők kapcsolata kerül összehasonlításra tájszinten. Az egyes típusok lokális élőhelymintázatát kisebb mintaterületekre készült élőhelytérképek szemléltetik.

A homoki tájak a garmada-buckamezők vagy a lepelhomok-hátak, maradékgerincek dominanciája - mint a táj alapmátrixát képző felszínalaktani formák alapján különülnek el. A futóhomokból álló, intenzívebb reliefü, széleróziónak jobban kitett garmadamezőket humuszos homoktalajok fedik, ám e garmadák talajainak humusztartalma kisebb a lepelhomok-hátakhoz, maradékgerincekhez képest (Bodrogközy 1981), s a beszivárgást lassító üledékek - s így a talajvíz is - e felszínformák alatt mélyebben helyezkednek el (Kuti et al. 1991). E területek így beszivárgási zónáknak számítanak, így biomassza-produkciójuk kisebb. A buckamezők vegetációját a nyílt homokpusztagyepek alapmátrixába ékelődő homoki nyarasok, illetve nyílt homoki tölgyesek alkotják. A Dél-Kiskunság homoki nyarasaiból hiányzik a közönséges boróka (Juniperus communis), azt az egybibés galagonya (Crataegus monogyna) helyettesíti, így e társulásra a galagonyás-nyaras (Crataego-Populetum albae) elnevezés javasolt. E nyilt homoki gyepekkel és erdőkkel mozaikos garmadabucka-mezős homoki táj a Duna-Tisza köze középső, kiemeltebb részén - lásd Kiskunsági-, Bugaci-homokhát, Illancs - jellemző.

Ezzel szemben a Dorozsma-Majsai-homokhát, a Pilis-Alpári-homokhát és a Túrján-vidék táji alapmátrixát a maradékgerincek és lepelhomok-hátak képzik, amelyek szintén futóhomokból épülnek fel, humuszos homoktalajjal fedettek. A felszín közelében e tájakban gyakran vízzáró vagy vizet nehezen áteresztő rétegek (réti dolomit, réti mészkő, mésszel összecementált homok) helyezkednek el (Miháltz 1966), ami miatt a talajvíz a gyökérzónához közelebb helyezkedik el, javítva a talajok vízgazdálkodási tulajdonságait. Ráadásul a fenti tájak, mivel a Duna-Tisza köze peremén helyezkednek el, nemcsak a helyben lehullott csapadékból, hanem a regionális talajvízáramlásokból, azaz a Duna-Tisza köze középső, garma- 
dabuckák uralta területei felöl is kapnak vízutánpótlást. Így a talajok humusztartalma is magasabb (Bodrogközy 1981) a nagyobb mennyiségü biomassza-produkció miatt. Ezért e felszínformák gyepei és erdei is zártak, homoki sztyepprétek, zártabb, egybibés galagonyát tartalmazó homoki nyarasok, s nyílt homoki tölgyesek mellett a zárt alföldi kocsányos tölgyesek is jellemzők. A lepelhomok-hátakba az uralkodó széliránynak megfelelően északnyugat-délkelet irányú szélvájta mélyedések (szélbarázdák, deflációs laposok, helyi néven: semlyékek) ékelődnek, amelyek vegetációmintázatát a felszín közeli vízzáróbb üledékek (réti mészkő, réti dolomit), a talajvízáramlások, a csapadék, a párolgás és a sófelhalmozódás befolyásolja. A Dorozsma-Majsai-homokhát és a Pilis-Alpári-homokhát szélbarázdáiban a semlyékek északnyugati részén lápi élőhelyek (láprétfö), míg azok délkeleti részén, a felszínformák legmélyebb fekvésủ területein szikes élőhelyek (szikalj) találhatók. Eme különösen a Dorozsma-Majsai-homokhátra jellemző lokális élöhely-mintázatot láprétfö-szikalj mintázatnak nevezzük (2. ábra). A láprétfö-szikalj mintázatú semlyékekben egy északnyugat-délkelet irányú grádiens mentén rendeződnek egymás mellé a különböző élőhely- és talajtípusok a vízellátottság és a talajok sókoncentrációjának függvényében. A láprétfơknél réti talajok találhatók,

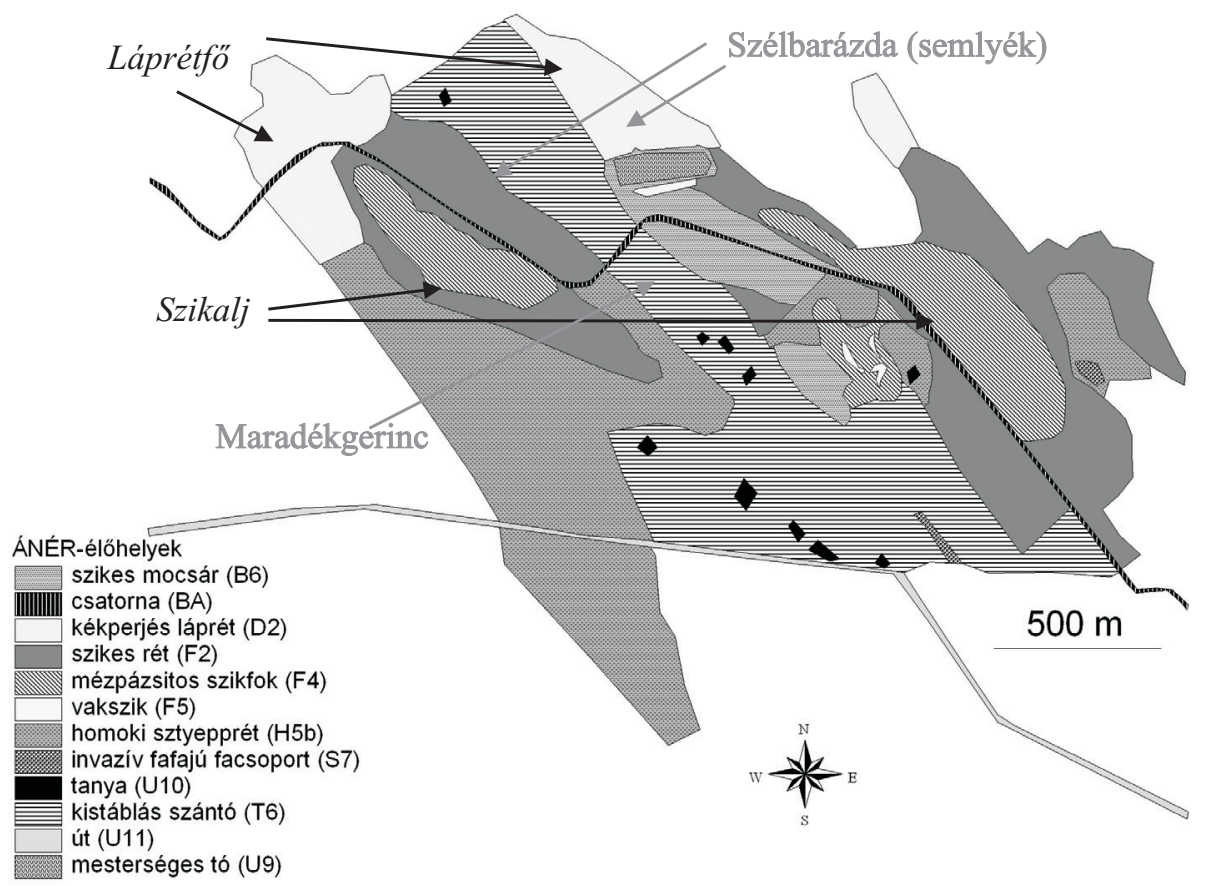

2. ábra. A Kisiván-szék és a Sáros-szék élőhelytérképe. A szürke nyilak és feliratok felszínalaktani formát, a dőlt betü pedig élőhelykomplexet jelöl. 
amelyeken kékperjés rétek, üde láprétek, magassásrétek, sédbúzás mocsárrétek, lápi magaskórósok jellemzők, de ott a szukcesszió későbbi fázisában üde cserjésekhez sorolható rekettyefüzesek, majd alföldi zárt kocsányos tölgyesek jelennek meg. A lápi zsombékosok, tőzegképző nádasok, füzlápok, kőris-és égerlápok a lápos réti talajú, magasabb talajvízszintü, legfeljebb nyár végére kiszáradó láprétfők élőhelyei, amelyek csak a fö regionális talajvízfeltörési zónáknál fordulnak elő. A láprétfők élőhelyeit délkelet felé először a szolonyeces réti talajon kialakult szikes rétek (így ezekre a „szoloncsákos szikes rét” elnevezés helyett a homokhátsági szikes rét elnevezés jobb) övezik, majd a legdélkeletebbi, legmélyebb fekvésü részeken, szoloncsák, illetve szoloncsák-szolonyec talajon - a magasabb pH-t, felszíni sófelhalmozódást indikáló - mézpázsitos szikfokok, vakszikek követik. A legtovább vízborította részeken szikes mocsarak is jellemzőek. A fenti grádiens mentén a lápi jellegü élőhelyek felöl a szikes élőhelyek felé haladva a szélbarázdákban az összsó-tartalom és a pH nö, míg a szerves anyagtartalom csökken a Balástya környékén elvégzett talajvizsgálatok alapján (Deák \& Bárány-Kevei 2011). A láprétfö-szikalj mintázat jól korrelál a regionális talajvízáramlások irányával, a felszíni és a felszín alatti rétegek lejtésével, de e mintázat kialakulásában fontos szerepe van az evapotranspirációnak (párolgás), illetve a felszín közeli vízzáró, félig vízzáró réti mészkő, réti dolomit, szikes iszap rétegeknek is, amelyek e talajvízáramlásokat a felszín közelében tartják. A talajvíz először a szélbarázdák északnyugati-nyugati részén jelenik meg, ahol a felszín belemetsz ezen áramlásokba. Ezután a víz a semlyékekben délkelet felé áramlik tovább a felszínen vagy a felszín közelében, amelyre azonban egyre jobban hat a párolgás, így az a szikaljba érve betöményedik, a talajoldatok sókoncentrációja, pH-ja megnő, ami a szikes élőhelyek kialakulásának kedvez. A párologtató vízgazdálkodás a szikesek létrejöttében meghatározó. Ha a regionális talajvízáramlások erőssége nagy, vagy a párologtató vízgazdálkodás kevésbé erôs (lásd a Felső-Kiskunság), akkor a szikes élőhelyek kisebb arányban, átmeneti formában jelennek meg, azokat legfeljebb a szikes rétek, szikes mocsarak képviselik, de a szikes élőhelyek hiányozhatnak is. A Túrján-vidék szélesebb felszíni mélyedései (ezek egy része félig eltemetett Ös-Duna meder) közvetlen a beszivárgási zónát jelentő, Duna-Tisza köze középső részén elhelyezkedő garmadabucka-vidék nyugati oldalán húzódnak, ami nagy relatív relieffel törik le nyugat felé (a Duna-Tisza-közi Homokhátság aszimmetrikus morfológiájú, legmagasabb pontjai annak nyugatabbi részén találhatók). Így a regionális talajvízáramlások is rövidebb távolság és idő alatt, nagyobb erővel érik el a felszín mélyedéseit kedvezve a lápi élőhelyeknek, amit a Túrján-vidéktől nyugatra a Duna-menti-síkság üledékei is elősegítenek, megakadályozva a talajvizek gyors nyugat felé való eláramlását. Ezzel szemben a Dorozsma-Majsaihomokhátság és a Pilis-Alpári-homokhát lassan, folyamatosan lejt délkelet felé, ahol a talajvízáramlások csak több $10 \mathrm{~km}$ megtétele után folyamatosan jutnak a 
felszínre, a felszín közelébe. Így ott van hely és idő a szikesek megjelenéséhez is a fö talajvízfeltörési zónától távolodva. A Dorozsma-Majsai-homokhát láprétföszikalj mintázatú semlyékeinél egy kistájszintű regionális mintázat is kirajzolódik a szikes és lápi jellegü élőhelyek egymáshoz viszonyított aránya tekintetében. A kistáj keleti széle felé a semlyékekben megnő a szikes élőhelyek aránya, a semlyékek legmélyebb részeit egyre gyakrabban töltik ki mézpázsitos szikfokok, alig vannak lápi jellegü élőhelyek. A lápi élőhelyek semlyékeken belüli aránya viszont a kistáj nyugati része felé haladva nő, miközben a fő talajvízfeláramlási zónákban az üdébb lápi élőhelyek (lásd zsombéksásosok) is gyakoribbak. E gradiensek alapján a Dorozsma-Majsai-homokhát háromosztatú. A nyugati harmadban, a kistáj Bugaci-homokháttal, Illanccsal határos részén a semlyékeket vastagabb futóhomok tölti ki, így a vízzáró rétegek és talajvíz mélyebben helyezkedik el. Itt a semlyékekben homoki sztyepprétek, sztyepprétesedö üde (szikes és lápréti) gyepek jellemzőek, amelyek kialakulásában a tájléptékü talajvízszint-süllyedés is szerepet játszhatott. A középső harmadban típusos láprétfö-szikalj mintázatú gyepek vannak, a láprétfő́k aránya itt a legnagyobb. A keleti harmadban viszont a szikes élőhelyek dominálta semlyékek jellemzőek, a lápi élőhelyek részaránya kicsi vagy hiányoznak is, mint azt a Kancsal-tó példája mutatja (3. ábra). A fenti laposabb homokformák uralta homoki tájak a láprétfö-szikalj mintázatú semlyékkel,

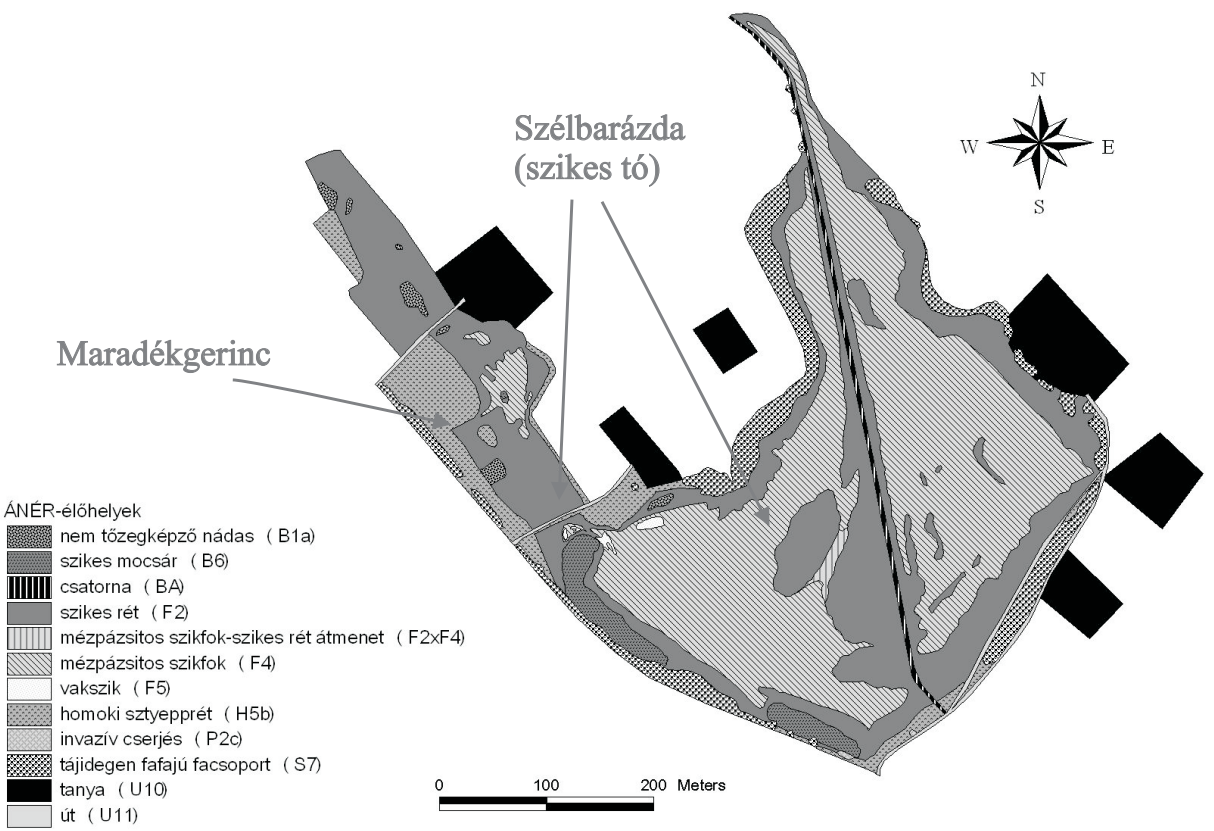

3. ábra. A Kancsal-tó élőhelytérképe. A nyilak felszínalaktani formákat jelölnek. 
sztyepprétekkel és erdőkel mozaikos homoki tájtípusba sorolhatók. A szélbarázdák üde élőhelyeit a csapadékhiány mellett a talajvízszint süllyedése (Szalai 2011) és a melioráció fenyegeti, ami nemcsak a vízellátottságot csökkenti, de a vízben oldható Na-sók koncentrációjának csökkenése a talajban (kimosódás, elszállítódás) a szikesek fennmaradását is veszélyezteti, ami a vakszikek és mézpázsitos szikfokok kiterjedésének csökkenésén, helyettük szikes rétek megjelenésén, illetve a szikes rétek gyomosodásán (tarackbúzásodás) is tetten érhető (Ladányi et al. 2011).

A lösszel fedett hordalékkúp-síkságok (lásd Körös-Maros köze, Nagykunság, Kelet-Duna-Tisza-közi löszhátak kistájcsoport (Gerje-Perje-sík, Kiskunságilöszöshát, Szegedi-sík), Bácskai-löszhát) élőhelyi mintázatát a jégkorszaki, lösz által konzervált felszínforma-kincs (löszhátak és elhagyott ősmedrek) határozza meg, de szikeseiken jelentős a felszíni leöblítés és a legeltetés irányította padkaerózió által feltáruló szikes altalaj szukcessziót és dinamikai folyamatokat befolyásoló hatása is (lásd nagyéri Gulya-kút mintaterület) (4. ábra). E crisicumi lösztájak pusztái a löszgyepekkel és pusztai tölgyesekkel mozaikos löszháti padkás összikesek vegetációs tájtípusba sorolhatók, amelyek 3 élőhelykomplexet foglalnak magukba: a löszhátak löszgyep-löszcserjés-lösztölgyes mozaikjait, az ősmedrek üde szikes élőhelyeit és az e kettő közt elhelyezkedő padkás szikeseket. A löszhátak löszgyep-löszcserjés-lösztölgyes mozaikjait sokszor csak a löszsztyepprétek képviselik, helyükön sokszor csak nagytáblás szántók dominálta szántók uralta mezsgyés, csatornás lösztáj található. A természetesebb, szikeseket is tartalmazó élőhelykomplexek belső, lokális élőhely-mintázata aprófoltos, élőhelydiverzitása nagy az abiotikus feltételek változatosságának és a tájhasználatnak köszönhetően. A crisicumi padkás ősszikesek egymással szukcesszionális és dinamikai kapcsolatban álló élőhelyei a geomorfológiai, talajtani, vízrajzi adottságoknak megfelelően zónákba rendeződnek. A természetföldrajzi adottságok kis mértékủ módosulása esetén is azonban a zónák képesek átrendeződni, mert a só- és vízellátottság az egyes élőhelyek kialakulásában, megjelenésében meghatározó. Ezen élőhelykomplex mintázatát minden más hazai élőhelykomplexnél jobban meghatározzák a mikromorfológiai adottságok, ugyanis az eróziós hatások hoszszú ideig megmaradnak. A puszták ősmedreiben, sarlólaposaiban nádasok, szikes mocsarak, szikes rétek található szolonyeces réti talajon. Az ősmedrekben szoloncsák-szolonyec talajon megjelenő mézpázsitos szikfokok, vakszikek a Kelet-Duna-Tisza-közi-löszhátakon gyakoribbak (különösen a Kiskunságilöszösháton), míg DK-Magyarország földrajzi Tiszántúlra eső részén ritkák (lásd Kardoskúti Fehér-tó, Kakasszék). A legnagyobb élőhelydiverzitás az övzátonyok, folyóhátak peremén jellemző, ahol réti szolonyec talajon ürmöspuszták, vakszikek, löszsztyepprét-maradványok, s az övzátonyokat feldaraboló szikerek szikes 
ÁNÉR-élőhelyek

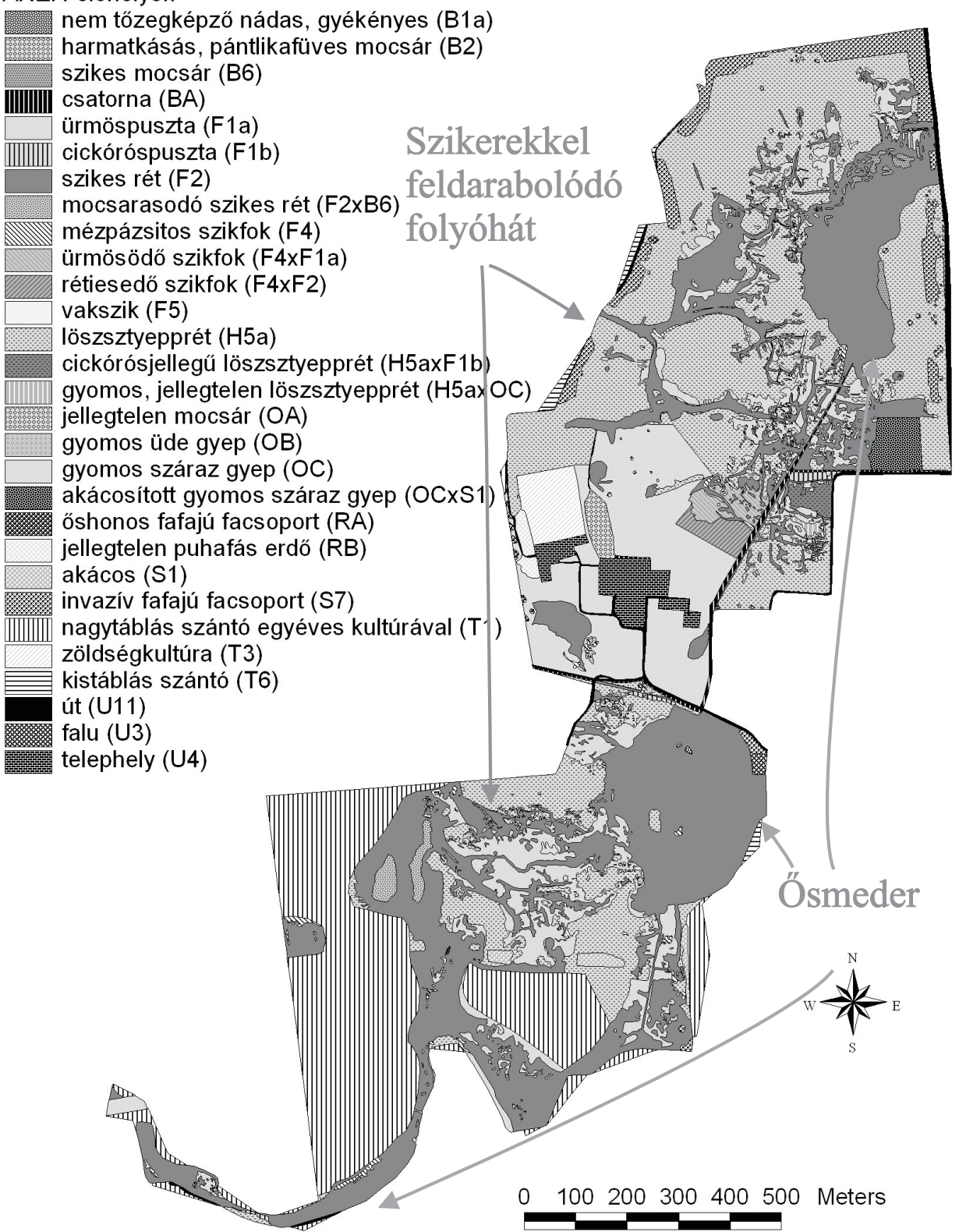

4. ábra. A Nagyéri Gulya-kút élőhelytérképe. A nyilak felszínalaktani formákat jelölnek. 
rétjei, mézpázsitos szikfokai jelennek meg. A kiemeltebb lösszel fedett folyóhátak, övzátonyok réti csernozjom, réti csernozjom, alföldi mészlepedékes csernozjom talajain az utolsó természetes növényzetet a löszsztyepprétek (ritkábban löszcserjések, lösztölgyesek) képviselik. A fenti élőhelymintázat jellemző az alacsony árterekbe ékelt, azokból szigetszerüen kiemelkedő magas ártéri lösz-maradványfelszínekre is, (lásd Solti-sík (Közép-Duna-sík), Körösszög, Bánság-sarok, Bihari-sík tájakat ezek uralják), hisz azok lösszel fedett hordalékkúpok folyóvízi erózió által feldarabolt maradványai, így e két formacsoport üledéktani, talajtani, morfológiai, klimatikus adottságai is hasonlóak. Mindkét formacsoportnál a recens elöntések hiánya és a folyók áradási miatt felszín közelében tartott talajvízszint is hozzájárult a szikesek kialakulásához. Napjainkban az árvizek hiányában csökkenő talajvízszint elősegíti e szikesek kilúgozódását, ami az ürmöspuszták cickóróspusztává történő átalakulásán érhető tetten.

Az ártereken az árvízi elöntés megléte vagy hiánya hat leginkább a táji mintázatra. Az elöntés viszonyok folyamatos változása, kiszámíthatatlansága és a tájhasználat jelentős élőhelyi diverzitást hozott létre, amit a folyamszabályzás és az ármentesítés is befolyásolt növelve a tájtípusok számát, s részben az élőhelydiverzitást is. Az ártereken 5 vegetációs tájtípus különíthető el (hullámtéri táj, mentett oldali nem szikes alacsony ártéri táj; ártéri lápi táj; mentett oldali alacsony ártéri másodlagos szikes táj; mentett oldali magas ártéri maradványfelszinek). A hullámterek friss öntésein (agyag, iszap, homok, homokliszt) öntés és réti öntés talajok, míg a mentett oldali nem szikes alacsony ártér kőzetliszt, iszap, agyag üledékein inkább öntés réti és réti talajok találhatók. A nem szikes ártér (hullámtéri táj, mentett oldali nem szikes alacsony ártéri táj) élőhelyeinek típusát, térbeli elrendeződését, mintázatát első sorban a hidroökológiai paraméterek (a talajvíz mélysége, dinamikája, a vízborítás eredete (árvíz vagy belvíz által), magassága, kezdete, tartóssága, éves - több éves dinamikája, vízutánpótlás formája, vízkémiai jellege) befolyásolják a tájhasználat mellett. Az elöntés hosszának, magasságának éves, több éves változásai a parti zonáció eltolódását, átmeneti állományok kialakulását, aprófoltosságot idéznek elö különösen a sekélyebb vizü ártéri vízterekben (hullámtéri holtágak, kubikgödrök, mentett oldali ómerdek, sarlólaposok). A nem szikes ártereken 15 természetes élőhely alkalmazkodott a fenti változó adottságokhoz. Közülük a mocsárrétek és a füz-nyár ligeterdők a legnagyobb kiterjedésúek táji léptékben. A mocsárrétek a Körösök vagy a Maros mentén a hullámtéren is nagyobb kiterjedésben megmaradtak, míg a Dél-Tiszavölgyben inkább csak a mentett oldalon fordulnak elö. A füz-nyár ligeterdők a hullámterek legnagyobb kiterjedésủ természetes élőhelyeivé váltak az elmúlt egy évszázad alatt, kiterjedésük a folyamszabályzások után telepítés és spontán regeneráció által is nőtt. A tápanyagban gazdag holtmedrekben, kubikgödrökben 
jellemzőek az eutróf hinarasok. A vízterek parti zonációjában és a feltöltődött medrekben a vízellátottságtól és annak sokéves változásaitól függően nem tözegképző nádasok, gyékényesek, tavi kákások; harmatkásás és virágkákás, csetkákás, hídőrös, mételykórós mocsarak társulásai; magassásrétek, míg a hirtelen kiszáradó vízterekben ártéri ruderális gyepek fordulnak elö. A nem szikes alacsony ártéri tájak élőhelyei mellett az ártereken valamennyi hazai szikes élőhely (9 darab) megtalálható köszönhetően az ártérbe ékelt magasártéri lösz-maradványfelszineknek és kisebb arányban az alacsony ártereken a folyamszabályzás után kialakult, kisebb élőhelydiverzitású másodlagos szikeseknek. Továbbá 5 lápi jellegü élőhely (lápi hinarasok, láptavi hinarasok, zsombéksásosok, füzlápok, égerlápok) is előfordul (ártéri lápi táj, lásd Tőserdő). Így az árterek eltérő természeti adottságaihoz összesen 29 élőhely alkalmazkodott az Alföldön. A legnagyobb élőhelyi diverzitás ott van, ahol a hullámtéri táj és a lösz-maradványfelszínek érintkeznek (lásd Tőkei-gyepek). A mentett oldali alacsony árterek másodlagos szikesei az elöntés jelenlegi hiányának köszönhetik kialakulásukat (föleg az árterek peremén), ugyanis az elöntések elmaradásával kifejezésre tudott jutni a párologtató vízgazdálkodás. A belvízelvezetés megindulásáig a folyók által felszín közelben tartott, $\mathrm{s}$ a környezö hordalékkúpok felől víz és Na-sóutánpótlást is kapó talajvíz is segítette a szikesedést. A cickórós másodlagos szikesek vegetációmintázatában főleg a

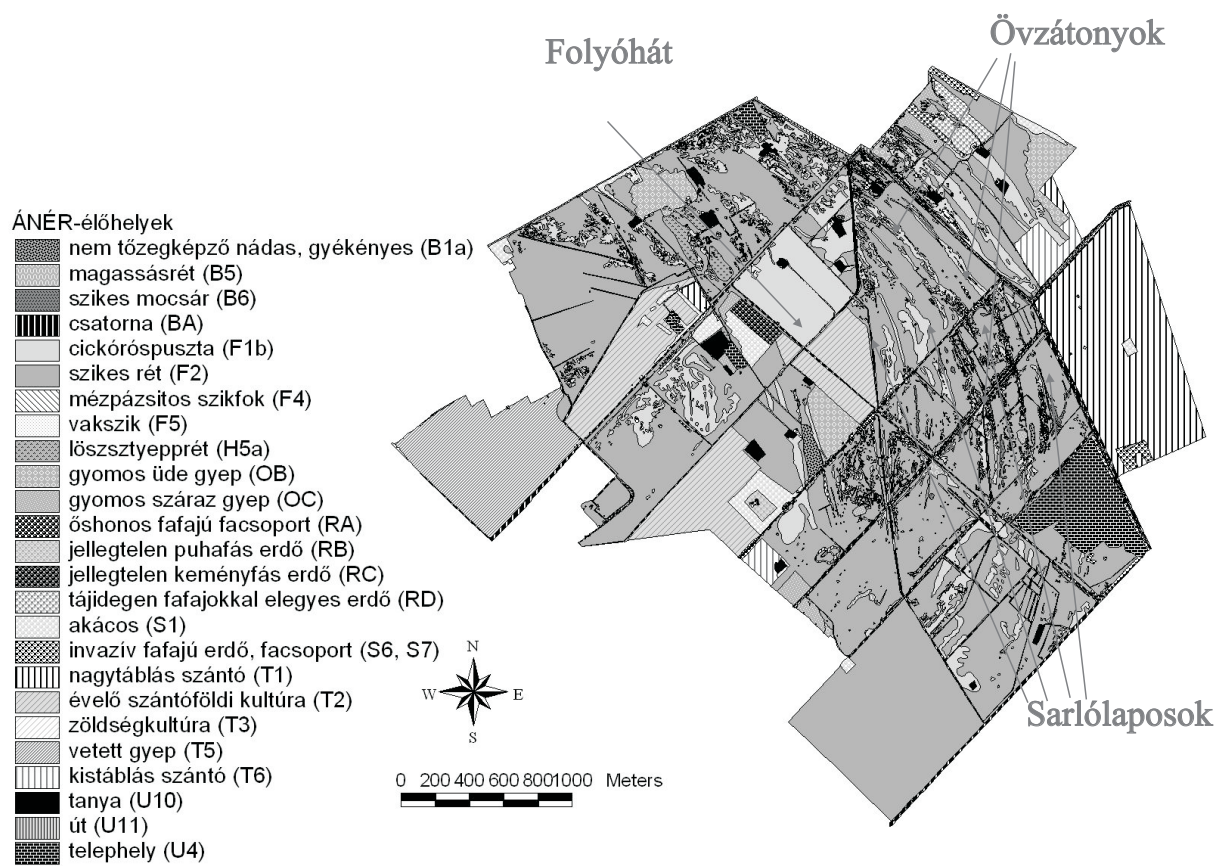

5. ábra. A hódmezővásárhelyi Nagysziget élőhelytérképe. A nyilak felszínalaktani formákat jelölnek. 
morfológiai adottságok meghatározóak (5. ábra), ami alapján 3 vegetációs alegység különíthető el. A hódmezővásárhelyi Nagysziget mintaterületén a homogén szikes rétek sarlólaposokban, ómedrekben felszín közeli, 0-0,5 m mély átlagos évi talajvízszintnél, réti szolonyec, réti, karbonátos öntés réti, réti öntés talajokon jelennek meg. A homogén cickórósok folyóhátakon, mélyebb - 1,3-2,0 m - átlagos évi talajvízszintnél alakulnak ki nem szikes, karbonátos humuszos öntés és karbonátos humuszos öntés réti talajokon. A szikes rétek és cickóróspuszták mozaikjai övzátonyokon, $0,1-1,3$ m- es átlagos évi talajvízszintnél, réti szolonyecen fordulnak elő. A rétsztyeppes másodlagos szikesek a fentiekhez hasonlóak, de bennük nagyobb arányban megjelennek az őszirózsás rétsztyeppek is (pettyegetett őszirózsával (Aster sedifolius ssp. sedifolius)), amelyek a fenti felszínformák bármelyikén kolonizálhatnak, de inkább az ősmedrekre és az övzátonyok ősmedrek körüli peremére jellemzőek. Az őszirózsás rétsztyeppek jó részt mélyben sós réti csernozjomon, sztyeppesedő réti szolonyecen fordulnak elő. E talajok átmeneti jellege jelzi ezen élőhelyek fajkészletének átmeneti jellegét is, mert abban a mocsárrétek, löszgyepek és szikes rétek fajai is előfordulnak. A belvízelvezetés és a csapadékhiány miatt a másodlagos ártéri szikek kilúgozódása is megkezdődött, amit szerves anyag-felhalmozódás kísér.

\section{Értékelés}

A hazai földtudomány egyes részterületei a természetföldrajzi adottságok térképezését jelentős különbségekkel valósították meg részletesség, területi lefedettség és aktuális szempontjából, így ezen adatbázisok eltérő mértékben használhatók fel az ökológia számára. A felhasználásnak komoly térlépték korlátai vannak, ugyanis a földrajzi adatbázisok gyakran csak tájléptékủ mintázatok értékelésére használhatók. Az Alföld Földtani Atlasza sorozat (Rónai et al. 1974, 1978, 1979, 1980, 1983, Kuti et al. 1991) nem készült el a teljes vizsgált területre, ám a frissebb 1:100.000-es digitális felszíni üledéktani térképek (MÁFI 2005) jól használhatók. A régebbi atlaszsorozat az átmeneti üledékek bemutatásánál jobban használható, az a 2, 5 és 10 m-es mélységben lévő üledékek térbeli mintázatát is tartalmazza, ami például a talajvízáramlások, a talajok víztartó-képessége szempontjából fontos. A talajvizek, rétegvizek helyzete, áramlási viszonyai, az egyes üledékrétegek és a talajok víztartó-képessége szempontjából kiemelkedő fontosságú az üledékek felső 30 m-ének vizsgálata (lásd 1:200.000-es felszíni üledékeket bemutató térképlapok az Alföld Földtani Atlaszában, Miháltz 1966). Mivel nincsenek kellő részletességủ geomorfológiai térképeink - legfeljebb lokális szinten (lásd Mezősi 1984) -, ́́gy azt a terepi tudás valamint az 1:10.000- es (FÖMI 1977-1983) és 
1:25.000-es (MH 1992) topográfiai térképek segítségével kell előállítani. A Magyarország Nemzeti Atlaszában lévő 1:500.000-es geomorfológiai térképen (Pécsi 1972) a földtani térképek és a geomorfológiai térképek fogalmai keverednek. Magyarország éghajlati atlasza (Merisch et al. 2001) csak a mezoklimatikus különbségek középtájszintü értékelésére használható. Részletesebb időjárási, klimatikus adatok az OMSZ mérőállomás-hálózat adataiból nyerhetők, amelyek sokszor még a kisebb települések esetén is az 1930-as évektöl kezdve folyamatos adatsort szolgáltatnak. Szintén akár az 1930-as évekig visszamenően egyes területekről folyamatos talajvíz-adatsorok állnak rendelkezésre a talajvízszintmérö-kút hálózatból. A korábbi talajvíztérképekhez (Rónai \& Boczán 1966, Rónai et al. 1974, 1978, 1979, 1980, 1983, Kuti et al. 1991) képesti változásokat mutatja be az 1971-2000. közötti átlagos talajvízszintek és a 2009. évi közepes talajvízszintek közti különbségeket ábrázoló országos térkép, valamint az 1971-2000 közti időszak december havi átlagértékei és a 2010. december havi közepes talajvízszintek közti különbségek területi eloszlását bemutató országos térkép (Szalai 2011). Előbbi térkép az 1980-as évektől megindult - föleg a Duna-Tisza közi Homokhátság központi részét érintő, de a Kis-Sárrétben, a Körös-Maros köze nyugati részén is jellemző - talajvízszint-süllyedést jelzi, míg az utóbbi a 2010-es kiemelkedő éves csapadékbevétel talajvízszint-süllyedést kompenzáló hatását mutatja be. Ez utóbbi alapján csak a Duna-Tisza közi Homokhátság egyes területein (lásd Illancs, Ásotthalom és a Pilis-Alpári-homokhát Kecskemét-Pusztavacs-Cegléd-Nagykőrös által határolt térsége) volt hatástalan a talajvíz szintjére a 2010-es csapadékbevétel. A folyók - kevesebb helyen a csatornák, tavak - vízszintváltozásaira a vízügyi igazgatóságok által üzemeltetett vízmércék adatai adnak tájékoztatást, de ezek is csak bizonyos településekre, vízterekre szolgáltatnak adatokat, így felhasználhatóságuk korlátos. A talajok térbeli mintázatát legrészletesebben az 1:25:000es Kreybig-féle talajtérkép (MKFI-MÁFI 1934-1951) mutatja be, de az csak a talajok víztartó-képességre, kémhatásra, szikességre koncentrál, az erdők és az olykor időszakosan elöntött területek talajait nem vizsgálja. A hazánkban legelterjedtebb, s a vegetációkutatásban is leginkább használt Stefanovits-féle genetikai talajosztályzás (Stefanovits 1999) egyetlen országos lefedettségü, aktuális adatbázisa az agrotopográfiai térkép (AGROTOPO 2002) amely csak legfeljebb kistáji-, középtáji szinten alkalmazható. Részletesebb genetikai talajtérképeket egyes feledésbe merülő Tsz-talajtérképek, illetve egyes lokális vizsgálatok jelenthetnek, amelyek legtöbbször nem megkerülhetők egy-egy vizsgálati terület talajtani jellemzőinek meghatározásához. Angolszász hatásra Magyarországon is megjelent a FAO-talajosztályzás (FAO-UNESCO 1988), ami az 1:500.000-es Európa Talajatlaszának (Jones et al. 2005) is a jelkulcsa. Ez csak részben hasonlít a Stefanovits-féle genetikai talajosztályzáshoz, abban vannak a hazai osztályzás 
logikájával nehezen értelmezhető, gyakran redundáns kategóriák is. A nevezéktannak nincs magyarra fordított hivatalos változata, ami minimum a gyakorlattal, de sokszor a társszakmákkal való kommunikációt is nehezíti. Délkelet-Magyarországon a kategóriák használatában és a térkép által közvetített táji mintázatban is problémák vannak. Hibásan kerültek egy kategóriába, a magyar nevezéktanban nem szereplö feozem talajtípusba (vastag, sötét, szerves anyagban gazdag feltalajú talajok, amelyekben nincs másodlagos $\mathrm{CaCO}_{3}$ felhalmozódás) a lepelhomok-hátak, maradékgerincek humuszos homoktalajai, a Dél-Tisza-völgy öntés és réti talajai és a réti csernozjomok, amelyek genetikailag, a talajképző kőzet, számos talajfizikai (lásd szemcseméret-eloszlás) és talajkémiai tulajdonság (lásd szerves anyagtartalom) alapján sem sorolhatók egy kategóriába. Az arenosol-ba sorolt garmadabucka-mezők futóhomokjainak ábrázolása a Duna-Tisza-köze déli részén pontatlan. A Felső-Kiskunság lepelhomok-hátainak humuszos homoktalajainak cambisol-ként (mérsékelten fejlett fiatal talajok) való elkülönítése szükségtelen. A fluvisolok (folyami talaj) az öntéstalajoknak feleltethetők meg, ám ezek ábrázolása hiányos, az országhatárnál megszakad. Az ártereken a szerves anyag felhalmozódás túlreprezentált, ugyanakkor a félig lebomlott szerves anyagot tartalmazó talajként definiált, tőzeges láptalajoknak megfeleltethető histosol-ok ábrázolása a Kis-Sárrétben pontatlan és historikus. A fentiek miatt a geomorfológiai és talajadottságok tisztázására az egyes tájtípusok és mintaterületek esetén a terepbejárások tapasztalatainak, talajvizsgálatoknak meghatározóbb szerepük volt a rendelkezésre álló földrajzi adatbázisokhoz képest. A talajtérképek általában csak fogódzót adtak, a tájléptékü mintázat megértésében segítettek.

A tájökológiai adottságok, a potenciális vegetáció meghatározását, illetve a tájváltozások detektálását a történeti térképek is segítik (lásd első (HIM 17641787), második (HIM 1806-1869), harmadik katonai felmérés (HIM 1872-1887) és felújítása (HIM 1912-1925), MNH 1950, FÖMI 1977-1983). Ugyan a régebbi térképek (lásd első katonai felmérés) kevésbé pontosak, kevésbé jól illeszthetők a mai térképekhez (bár a második katonai felméréstől kezdődően ez már kevésbé problémás), azok tartalma mégis rendkívül fontos (lásd garmadabucka-mezők, szikes tavak, lápok, ártérhatár (elöntött és ármentes területek) meghatározása), ugyanis kombinálva azokat a geomorfológiai, hidrológiai és talajtani adatokkal, figyelembe véve az aktuális vegetációmintázatot - a növényzet tájléptékủ változásai, a potenciális vegetáció is meghatározható (lásd Duna-Tisza köze tájtörténeti térképei (Biró 1998, Biró \& Gulyás 1999). A CORINE (FÖMI 2000) és a CÉT (Molnár 2000) élőhelyek kombinált használatával (a nem természetes élőhelyekre előbbit, a természetes élőhelyekre utóbbit alkalmazva) tájtörténeti élőhelytérkép sorozatok szerkeszthetők (Deák 2003, 2004, Deák \& Bárány-Kevei 2006). 
A homoktájakban a geomorfológiai adottságok és a talajvíz szerepe a vizsgálatok alapján kiemelkedő, de a felszín alatti vízzáró rétegek épségének megőrzése (lásd réti mészkő, réti dolomit rétegek megóvása, öntözőgödrök létesítésének megakadályozása, szénhidrogén-kutatás mérséklése) is fontos a tájra jellemző csapadékeloszlás és csapadékösszeg mellett. Ezért mind a felszínmorfológia megváltoztatás (lásd homokbuckák elplanálása, szélbarázdák feltöltése, szél által szállított homokkal való eltemetődése), mind a talajvízszint csökkenése (lásd lápi élőhelyek eltünése, szikesek kilúgozódása) súlyos következményekkel jár. A bemutatott láprétfö-szikalj mintázat azt is jelzi, hogy a Homokhátság vizes élőhelyeinek vízutánpótlása (láprétek, szikes élőhelyek) természetszerúen csak a talajvíz utánpótlásával és nem felszíni vízutánpótlással lehet megoldani, mert az nem járul hozzá a fenti élőhelymintázat fenntartásához.

A lösztájak és a magas ártéri lösz-maradványfelszínek padkás szikeseinek táji mintázatában a geomorfológiai adottságok (nagyobb léptékben a jégkorszaki formakincs, lokálisan a mikromorfológia) a meghatározóak, amik a talaj és hidrológiai adottságokra is kihatnak. A vegetációmintázat formálódásában a padkaeróziónak (lineáris és areális) fontos a szerepe, amely segít az akár néhány cm-rel mélyebben lévő sós talajrétegek feltáródásában is. A padkaeróziót a legeltetés is segíti, amely egyben az aprófoltosság, a nagy foltszám, az élőhelyi diverzitás fenntartásában is fontos. A padkaerózió miatt nem a klasszikus szukcessziós folyamatok jellemzőek a löszháti padkás szikeseken, hanem a változó geomorfológiához igazodó füves élőhelyek térbeli mintázatának változása, ha a talajfelszín közelében marad a só. Sztyeppesedési folyamatok a talajban és a vegetációban csak a tápanyagok, szerves anyagok felhalmozódása esetén indulhatnak meg. A nem szikes lösztájakban a beszántás a fö veszélyeztető tényező, így a mezsgyéken fennmaradt keskeny löszsztyepprét (olykor löszcserjés) foltok megőrzése a természetvédelem fő feladata (Jakab \& Csathó 2014), ami a nem optimális geometria a nagy periméter-arány miatt igen nehéz.

$\mathrm{Az}$ árterek vegetációs tájtípusait alapvetően az árvizek megléte vagy hiánya határozza meg. Alapvetően a felszín morfológia és a hidrológiai adottságok kölcsönhatás a meghatározó a vegetációmintázatban, de az emberi tájhasználat más tájtípushoz képest kissé nagyobb - szerepe is fontos. A talajtípusok térbeli mintázatának az alacsony ártéri tájakban a legkisebb a hatása a vegetáció térbeli mintázatára. A vegetációmintázat befolyásolására a felszíni elöntés egyedül itt alkalmazható sikeresebben, bár a másodlagos szikeseknél ehelyett a talajvízen át történő hidrológiai környezet kialakítása a kedvezőbb. Az alacsony ártéri szikeseknek alacsony a sótartalmuk. A rétsztyeppes másodlagos szikesek átmeneti jellegü, egyszerre többféle hatást (sztyeppesedés (humusz-felhalmozódás), szikesedés, talajvízhatás) tükröző talajaik miatt sérülékenyek. Amennyiben a talaj- 
fejlődést befolyásoló folyamatok egyike túlsúlyba kerül az a vegetációmintázat átalakulását, esetlegesen a másodlagos szikesek jellegzetes indikátorélőhelyeinek (cickóróspuszták, őszirózsás rétsztyeppek) eltűnését eredményezheti.

Valamennyi tájtípusra jellemző a szikesek kilúgozódása, ami a talajvízszint felszín közelében való tartásával mérsékelhető. Ez a vízvisszatartásra, a csatornaszintủ vízvisszatartásra hívja fel a figyelmet. Ugyanakkor a nyári kiszáradás a bepárlódás biztosítása miatt szükséges.

Köszönetnyilvánitás - A kutatás a TÁMOP-4.2.1/B-09/1/KONV-2010-0005 „Kutatóegyetemi Kiválósági Központ létrehozása a Szegedi Tudományegyetemen” című projekt, a Körös-Maros, a Kiskunsági és a Hortobágyi Nemzeti Park Igazgatóságok, az MTA-ÖBKI, a Magyar Madártani és Természetvédelmi Egyesület, a Nimfea Természetvédelmi Egyesület, a BioAqua Pro Kft. és a Beretzk Péter Természetvédelmi Klub segítségével jött létre.

\section{Irodalomjegyzék}

AGROTOPO (2002): Agrotopográfiai adatbázis. - Magyar Tudományos Akadémia Talajtani és Agrokémiai Kutatóintézet, Budapest, elérhető: http://maps.rissac.hu/agrotopo/

Biró, M. (1998): A Duna-Tisza köze vegetációja a 18. században. Áttekintő térkép. Méretarány 1: 100.000. - In: Molnár, Zs. (szerk.): A Kiskunság száraz homoki növényzete. TermészetBúVÁR Alapítvány Kiadó, Budapest, 30 p.

Biró, M. \& Gulyás, Gy. (1999): A Duna-Tisza köze tájhasználati- és élőhelytérképe a 19. században. - In: Molnár, Zs. (szerk.): A Kiskunság száraz homoki növényzete. TermészetBÚVÁR Alapítvány Kiadó, Budapest, 32. p.

Bodrogközy, Gy. (1981): Hydroecology of the vegetation of sandy forest-steppe character in the Emlékerdő at Ásotthalom. - Acta Biol. Szeged. 27: 13-39.

Borsy, Z. (szerk.) (1992): Általános természetföldrajz. - Nemzeti Tankönyvkiadó, Budapest, 832 p. Bölöni, J., Molnár, Zs. \& Kun, A. (2011): Magyarország élőhelyei. Vegetációtípusok leirása és határozója ÁNÉR 2011. - MTA-ÖBKI, Vácrátót, 439 p.

CNES (1998): SPOT-4 müholdfelvételek. - Földmérési és Távérzékelési Intézet, Budapest.

Deák, J. Á. (2003): Landscape changes of the Lódri-tó-Kisiván-szék-Subasa area in the DorozsmaMajsaian Sandlands. - Acta Climatol. Chorolog. 36-37: 27-36.

Deák, J. Á. (2004): Aktuális és tájtörténeti élőhelytérképezés Csongrád környékén. - Természetvéd. Közlem. 11: 93-105.

Deák, J. Á. \& Keveiné Bárány, I. (2006): Landscape-ecological mapping in the surroundings of Szeged. - Ekológia 25: 26-37.

Deák, J. Á. \& Keveiné Bárány, I. (2011): Csongrád megye kistájainak élőhely-mintázata és tájökológiai szempontú értékelése. - In: Unger, J. \& Pál-Molnár, E. (szerk.): Geoszférák 2010. SZTETTIK Földrajzi és Földtani Tanszékcsoport, GeoLitera, Szeged, pp. 79-128.

FAO-UNESCO (1988): Soil map of the world. - World Soil Resources Report 60, FAO, Róma, elérhetö: http://www.fao.org/soils-portal/soil-survey/soil-maps-and-databases/faounesco-soilmap-of-the-world/en/

FÖMI (1977-1983): EOTR-térképek. Méretarány: 1:10.000. - Földmérési és Távérzékelési Intézet, Budapest. 
FÖMI (2000): CORINE Felszínboritás CLC50 nomenklatúra 1.4. - Kézirat. Földmérési és Távérzékelési Intézet, Budapest.

FÖMI (2005): Magyarország 2005-es légifotózásának ortofotói. - Földmérési és Távérzékelési Intézet, Budapest.

HIM (1764-1787): Első katonai felmérés térképei. Méretarány: 1:28.800. - Hadtörténeti Intézet és Múzeum Térképtára, Budapest.

HIM (1806-1869): Második katonai felmérés térképei. Méretarány: 1:28.800. - Hadtörténeti Intézet és Múzeum Térképtára, Budapest.

HIM (1872-1887): Harmadik katonai felmérés. Méretarány: 1:75.000. - Hadtörténeti Intézet és Múzeum Térképtára, Budapest.

HIM (1912-1925): Harmadik katonai felmérés felújított változatai. Méretarány: 1:75.000. - Hadtörténeti Intézet és Múzeum Térképtára, Budapest.

Jakab, G. \& Csathó, A. I. (2014): Keskeny mezsgyén: a fogyatkozó alföldi löszpuszták világa. - A Földgömb 2014(3): 56-65.

Jones, A., Montanarella, L. \& Jones, R. (szerk.) (2005): Soil atlas of Europe. - European Soil Bureau Network, European Comission, Office for Official Publications of the European Communities, Luxemburg, 128 p.

Kuti, L., Körössy, L., Papp, Lné. \& Urbancsek, J. (szerk.) (1991): Az Alföld földtani atlasza Kiskunhalas. - Magyar Állami Földtani Intézet, Budapest, 18 p.

Ladányi, Zs., Rakonczai, J. \& Deák, J. Á. (2011): A Hungarian landscape under strong natural and human impact in the last century. - Carpathian J of Earth and Environ. Sciences 6(2): 35-44.

Lóczy, D. (2008): Geomorfológia II. Felszíni folyamatok és formák. - Dialóg Campus Kiadó, Budapest-Pécs, $512 \mathrm{p}$.

Lóczy, D. \& Veress, M. (2005): Geomorfológia I. Felszíni folyamatok és formák. - Dialóg Campus Kiadó, Budapest-Pécs, 335 p.

Mattyasovszky, J., Görög, I. \& Stefanovits, P. (1967): Mezögazdasági talajtérkép Kreybig-féle térképszelvények és az Agrokémiai Kutatóintézet újabb felvételei alapján. - Tervgazdasági Könyvkiadó, Budapest.

MÁFI (2005): Magyarország földtani térképe. Méretarány: 1:100.000. - CD, Magyar Állami Földtani Intézet, Budapest.

MKFI-MÁFI (1934-1951): Kreybig-féle Átnézeti Talajismereti Térképezés. Méretarány: 1:25.000 Magyar Királyi Földtani Intézet - Magyar Állami Földtani Intézet, Budapest.

Merisch, I., Práger, T., Ambrózy, P., Hunkár, M. \& Dunkel Z. (szerk.) (2001): Magyarország éghajlati atlasza. - Országos Meteorológiai Szolgálat, Budapest, 107 p.

Mezösi, G. (1984): Szeged környékének negyedkori és recens felszínfejlődésének néhány kérdése a részletes geomorfológiai térképezések tükrében. - In: Rakonczai, J. (szerk.): Az Alföld gazdaságföldrajzi kutatásának eredményei és további feladatai. II. természeti környezet. MTA Földrajztudományi Kutatóintézet Alföldi Csoportja, Békéscsaba, pp. 203-212.

Mezősi, G. \& Rakonczai, J. (szerk.) (1997): A geoökológiai térképezés elmélete és gyakorlata. JATE Természeti Földrajzi Tanszék, Szeged, 131 p.

Miháltz, I. (1966): A Tisza-völgy déli részének vízföldtana. - Hidrol. Közlöny 1966(2): 74-89.

MH (1992): Gauss-Krüger topográfiai térképek. Méretarány: 1:25.000. - Magyar Honvédség Tóth Ágoston Térképészeti Intézete, Budapest.

MNH (1950): Magyar Néphadsereg topográfiai térképei. Méretarány: 1:25.000. - Magyar Honvédség Tóth Ágoston Térképészeti Intézete, Budapest.

Molnár, Cs., Molnár, Zs., Barina, Z., Bauer, N., Biró, M., Bodonczi, L., Csathó, A. I., Csiky, J., Deák, J. Á., Fekete, G., Harmos, K., Horváth, A., Isépy, I., Juhász, M., Kállayné Szerényi, J., Király, G., Magos, G., Máté, A., Mesterházy, A., Molnár, A., Nagy, J., Óvári, M., Purger, D., 
Schmidt, D., Sramkó, G., Szénási, V., Szmorad, F., Szollát, Gy., Tóth, T., Vidra, T. \& Virók, V. (2008): Vegetation-based landscape regions of Hungary. - Acta Botanica Hung. 50: 47-58. http://dx.doi.org/10.1556/ABot.50.2008.Suppl.4

Molnár, Zs. (2000): A CORINE Élőhelytérkép jelkulcsa. - Kézirat. MTA-ÖBKI, Vácrátót.

Molnár, Zs., Bartha, S., Seregélyes, T., Illyés, E., Botta-Dukát, Z., Tímár, G., Horváth, F., Révész, A., Kun, A., Bölöni, J., Biró, M., Bodonczi, L., Deák, J. Á., Fogarasi, P., Horváth, A., Isépy, I., Karas, L., Kecskés, F., Molnár, Cs., Ortmann-né Ajkai, A. \& Rév, Sz. (2007): A Grid-Based Satellite-Image Supported, Multi-Attributed Vegetation Mapping Method (MÉTA). - Folia Geobotanica 42: 225-247. http://dx.doi.org/10.1007/BF02806465

NTSZ (1980): A Lenin Tsz genetikai talajtérképe. Méretarány: 1:10.000. - Csongrád Megyei Növény- és Talajvédelmi Szolgálat, Hódmezővásárhely.

Pécsi, M. (1972): Magyarország geomorfológiai térképe. Méretarány: 1:500.000. - In: Pécsi, M. (szerk.): Magyarország Nemzeti Atlasza. Kartográfiai Vállalat, Budapest, pp. 30-31.

Rónai, A., Boczán, B., Boros, J. \& Körössy, L. (szerk.) (1979): Az Alföld földtani atlasza Szeged. Magyar Állami Földtani Intézet, Budapest, 18 p.

Rónai, A., Boczán, B., Boros, J., Kőrössy L., Kuti, L. \& Urbancsek, J. (szerk.) (1978): Az Alföld földtani atlasza Hódmezővásárhely. - Magyar Állami Földtani Intézet, Budapest, 18 p.

Rónai, A., Boczán, B., János, E., Kőrössy, L., Kuchen, Z., Kuti, L., Szepesházy, K. \& Urbancsek, J. (szerk.) (1980): Az Alföld földtani atlasza Gyoma. - Magyar Állami Földtani Intézet, Budapest, $18 \mathrm{p}$.

Rónai, A., Boczán, B., János, E., Körössy, L., Kuchen, Z., Szepesházy, K. \& Szűcs, I. (szerk.): Az Alföld földtani atlasza Orosháza. - Magyar Állami Földtani Intézet, Budapest, 18 p.

Rónai, A., Boczán, B., Wein, Gy., Polcz, I. \& Urbancsek, J. (szerk.) (1974): Az Alföld földtani atlasza Csongrád. - Magyar Állami Földtani Intézet, Budapest, 18 p.

Rónai, A. \& Boczán, B. (1961): Az Alföld talajvíztérképe, a talajvíztükör átlagos mélysége a felszín alatt. Méretarány: 1:200.000. - In: Rónai A. (szerk.): Az Alföld talajviztérképe. Magyar Állami Földtani Intézet, Budapest, 102 p.

Stefanovits, P. (1999): A talajok osztályzása; Főtípusok, típusok és altípusok. - In: Stefanovits, P., Filep, Gy. \& Füleky, Gy. (szerk.): Talajtan. Mezőgazda Kiadó, Budapest, pp. 239-314.

Szalai, J. (2011): Talajvízszint-változások az Alföldön. - In Rakonczai, J. (szerk.): Környezeti változások és az Alföld. Nagyalföld Alapítvány, Békéscsaba, pp. 97-110.

Takács, P. (1989): Csongrád megye középtávú öntözésfejlesztési koncepciójának talajtani megalapozása. - Gödöllői Agrártudományi Egyetem, Mezőgazdaságtudományi Kar, Gödöllö, 38 p. 


\title{
The role of geosciences in making habitat-maps and their evaluation on examples from Southeast Hungary
}

\author{
Áron József Deák, János Rakonczai and Zsuzsanna Ladányi \\ University of Szeged, Department of Physical Geography and Geoinformatics, \\ H-6722 Szeged, Egyetem u. 2., Hungary \\ e-mail:aron@geo.u-szeged.hu
}

\begin{abstract}
Physical geographyical conditions and their changes influence the appearance, spatial pattern and state of the objects of nature conservation (e.g. species, communities, landscapes). In the Southeastern Hungarian part of the Great Hungarian Plain the surface deposits, water supply and the geomorphological conditions have an increased role in the determination of the patterns of soils and biologic entities instead of macroclimatic features. On the base of the geographical background sand, loess and floodplain landscape types can be identified in this area. Sand landscapes are differed according to the matrix forming geomorphological forms in the landscape, namely according to the dominance of blow-out dunes or sand sheets. The habitat pattern of the deflation hollows is influenced by the near-to-surface deposits, precipitation income, evapotranspiration and the accumulation of salt. The habitat-pattern of the loss-covered alluvial cones is determined by the Pleistocene form-heritage, but the erosion of salt-berms driven by both surface runoff and grazing have an important role as well. In floodplains the unpredictable inundation or its lack influence the landscape pattern mostly beside the geomorphological conditions and landscape use resulting high habitat diversity. The habitat maps used as a tool for vegetation-mapping refer to the spatial patterns of the geographical background as well. Recent Hungarian geographical databases can usually be used just on landscape-level scale in order to understand the vegetation pattern.
\end{abstract}

Keywords: geosciences, landscape ecology, habitats, landscape pattern, abiotic conditions, Great Hungarian Plain, vegetation of plains, habitat mapping 